\title{
Urgences
}

\section{Cercles parallèles}

\section{Nicole Desrosiers}

Numéro 7, 2e trimestre 1983

URI : https://id.erudit.org/iderudit/025102ar

DOI : https://doi.org/10.7202/025102ar

Aller au sommaire du numéro

Éditeur(s)

Urgences

ISSN

0226-9554 (imprimé)

1927-3924 (numérique)

Découvrir la revue

Citer ce document

Desrosiers, N. (1983). Cercles parallèles. Urgences, (7), 27-32.

https://doi.org/10.7202/025102ar

Ce document est protégé par la loi sur le droit d'auteur. L’utilisation des services d'Érudit (y compris la reproduction) est assujettie à sa politique d'utilisation que vous pouvez consulter en ligne.

https://apropos.erudit.org/fr/usagers/politique-dutilisation/
Cet article est diffusé et préservé par Érudit.

Érudit est un consortium interuniversitaire sans but lucratif composé de l'Université de Montréal, l'Université Laval et l'Université du Québec à Montréal. Il a pour mission la promotion et la valorisation de la recherche. https://www.erudit.org/fr/ 
NICOLE DESROSIERS 


\section{CERCLES PARALLĖLES}

fallait-il ce temps retors

pour que pleuvent

les cercles parallèles

des cris

pour que dilatés les poèmes

crèvent

bulles d'eau glauques

à partir de jamais

l'oreille assourdie

ne repousse que ces tonnerres

avortés

au-delà de toute lassitude

abstraction nette

du sang

et des larmes

un chant peut-il être un chant

tant de gorges nues

et des maîtres comme des corbeaux

couards

les pleurs d'enfant

laissent insensibles

ces blanches liturgies

où les senteurs se meuvent

chauves-souris amorphes

quasi phosphorescentes

de plaisirs solitaires 


\section{TRANSHUMANCES}

ce jour offert à toute soif

délie son pli intact

devant

derrière

et me voilà

toute mésalliance niée

au cours de mes démarches tardives

où vont donc ces transhumants obscurs

au sang lessivé

dont j'aligne aujourd'hui les impostures

sereine intransigeance

issue de l'effritement de la cohorte

et me voilà

expulsée de la chaîne concentrique

hors des brisées salutaires

où se déconcertaient les apparences

à force de s'enrayer dans les embruns

les coques ébréchées

alignent leurs occupants clandestins

et divaguent 
qu'ai-je à faire de ta magnificence

les dieux ahuris ont-ils jamais admis

dans leurs conciliabules

les déments de l'effroi

que ne puis-je à présent

investie de ma conscience encore innommée

bannir ces déchirements occultes

innocentée

je t'entends

les degrés franchis

n'ont pas eu raison de ta voix

de mon souffle jaillissent des formes vacillantes de ma lèvre à l'air ne pas outrepasser le chant connu où ai-je déjà entrevu ces hordes de créatures courant sur le passavant la maïeutique n'est d'aucun secours en cas de départ 
te voilà enfin

évadé provisoire

d'un automne si prompt

que ma vigilance contournée

a perdu ses assises

mais oui je résiste

témoin assidue

du convoi exubérant

où je n'ai nulle part

comment te retenir

je perds pied dans ces ténèbres

où tu me presses

il doit être possible

de régénérer l'ultime présence

de ton sommeil étrange

j'écarte toute rupture

et la peur abhorrée

dors

les mots et les gestes assouplis

font déchanter les visiteurs importuns

qui balisent ton repos 
retirez-vous néfastes suspicions tiens des voix imprévues et pourtant nouvelle Niobé mon corps de pierre s'immobilise non ne venez pas adouber la reine sur sa route impondérable échec et mat

I'intaille douloureuse

scelle ce présent

ce présent grimé

au miroir burlesque

de navrantes facéties

et me voilà

j'avance

et pourtant

l'immobile incohérence

me prémunit

contre la prévisible chute 